\title{
Analysis of Stem Rust Resistance in Australian Barley Cultivars
}

L. Derevnina, University of Sydney, Plant Breeding Institute, Private Bag 4011, Narellan, NSW, 2567, Australia; T. Fetch, Cereal Research Centre, Winnipeg, Manitoba R3T 2M9, Canada; D. Singh, University of Sydney, Plant Breeding Institute; R. Brueggeman, Department of Plant Pathology, North Dakota State University, Fargo 58102; and C. Dong and R. F. Park, University of Sydney, Plant Breeding Institute

\begin{abstract}
Derevnina, L., Fetch, T., Singh, D., Brueggeman, R., Dong, C., and Park, R. F. 2014. Analysis of stem rust resistance in Australian barley cultivars. Plant Dis. 98:1485-1493.

Eighty-two Australian and five exotic barley cultivars were evaluated at the seedling stage for resistance to the Australian stem rust pathotype 98-1,2,3,5,6. Although most of these cultivars exhibited mesothetic (mixed infection type) reactions that were associated with a high level of chlorosis, two ('O'Connor' and 'Pacific Ranger') were highly resistant. Marker analysis indicated that four Australian cultivars ('Empress', 'Vlamingh', Pacific Ranger, and 'Yerong') possess the stem rust resistance gene Rpg1. Tests conducted using North American Puccinia graminis f. sp. tritici pathotypes MCCJ and QCCJ supported

marker results and indicated that 'Pacific Ranger' and 'Vlamingh' likely carry additional stem rust resistance genes. Based on pedigree information and results from multipathotype tests, these genes are believed to be uncharacterized and, therefore, new. The resistance in Australian barley 'Franklin' conferred resistance against all pathotypes tested in this study. Studies of inheritance to MCCJ revealed that it possessed an unknown seedling resistance, which was independent of and displayed additivity to Rpgl.
\end{abstract}

Stem rust, caused by Puccinia graminis, is one of the most devastating pathogens affecting cereals worldwide (40). In Canada and the Northern Great Plains of the United States, the wheat stem rust pathogen, $P$. graminis f. sp. tritici, has caused a number of significant epidemics on both wheat (Triticum aestivum and $T$. turgidum var. durum) and barley (Hordeum vulgare) (17). Although stem rust has not been a major problem in the United States for over 50 years, it is still considered the most destructive cereal rust disease (30). In Australia, levels of stem rust in wheat and barley crops and the diversity of $P$. graminis pathotypes recovered in pathogenicity surveys have been low since the early 1980s $(20,26)$. Although considerable research has been undertaken on stem rust of wheat in this region $(25,48,49)$, research on stem rust affecting barley has been limited. Until 1982, stem rust was regarded as being of minor importance to Australian barley crops. However, with severe epidemics in Queensland in 1983 and the occurrence of localized epidemics in 1984, it became evident that $P$. graminis could pose a serious threat to barley production in Queensland and northern New South Wales (8).

At present, stem rust tends to be a problem on barley in Australia only when inoculum levels are high due to epidemics in wheat or triticale because epidemics on these crops exert substantial inoculum pressure on barley crops (8). Due to the widespread planting of resistant wheat cultivars and conditions unfavorable for rust development, losses to stem rust in barley have been rare in many production areas (25). In Australia, barley crops may be affected by three physiological forms of $P$. graminis: the form virulent on wheat or triticale ( $P$. graminis $\mathrm{f}$. sp. tritici), the form virulent on cereal rye ( $P$. graminis $\mathrm{f}$. sp. secalis), and a putative

Corresponding author: R. F. Park, E-mail: robert.park@sydney.edu.au

Current address of L. Derevnina: University of California-Davis, Davis 95616 .

* The $\boldsymbol{e}$-Xtra logo stands for "electronic extra" and indicates that a supplementary table and a supplementary figure are available online.

Accepted for publication 21 April 2014.

http://dx.doi.org/10.1094/PDIS-11-13-1174-RE

(C) 2014 The American Phytopathological Society somatic hybrid between these two formae speciales, referred to locally as "Scabrum" rust $(18,25)$.

To date, eight stem rust resistance genes have been described in barley. Genes conferring resistance to $P$. graminis f. $\mathrm{sp}$. tritici are Rpg1, reported in 'Peatland' (CIho 5267), 'Chevron' (CIho 1111), and 'Kindred' (CIho 6969) (29,34,37); Rpg2 from 'Hietpas-5' (CIho 7124) (28); Rpg3 from 'PI 382313' (12, 13); rpg4 from 'Q21861' (PI 584776) (14); RpgU in 'Peatland' (11); and rpg6 from line '212Y1', an $H$. vulgare line with introgressions of $H$. bulbosum chromatin (10). Genes conferring resistance to $P$. graminis f. sp. secalis include $r p g B H$ (known formerly as $r p g S$ ) were found in 'Black Hulless' (CIho 666) (42) and Rpg5 (provisionally designated $\operatorname{Rpg} Q$ ) was reported in 'Q21861' (PI 584766) (45).

Although six resistance genes to $P$. graminis $\mathrm{f}$. sp. tritici have been described, stem rust control in barley has been largely achieved by the widespread use of a single resistance gene (Rpg1), previously designated as the T-gene (37). Rpgl was bred into North American barley cultivars to control the stem rust epidemics that plagued the Northern Great Plains of the United States during the first half of the 20th century (50). This gene conferring resistance to many pathotypes of $P$. graminis is dominant and is considered durable (15) because it remained effective for a long time in widely grown cultivars across the stem-rust-prone Northern Great Plains region. The durability of the Rpgl resistance gene is remarkable, considering the potential variability of the fungus and the vast hectares over which cultivars with this resistance gene were grown (37).

In the United States and Canada, barley cultivars with Rpg1 were first released in 1938 and 1942, respectively. Since that time, there have been no significant losses as a result of stem rust, except for a minor epidemic caused by pathotype QCCJ (virulent on Rpg1) in 1989 and $1990(14,37,50)$. Due to the absence of discriminating $P$. graminis f. sp. tritici in Australia, Rpgl cannot be detected via seedling tests (6); therefore, its presence and effectiveness in Australia is currently unknown. The aim of this study is to identify and characterize stem rust resistance genes in Australian barley cultivars.

\section{Materials and Methods}

Plant material. The pedigree information of 82 Australian and 5 exotic barley cultivars used in the present study is provided in Supplementary Table S1. Seed were obtained from the University of Sydney Germplasm Collection maintained at the Plant Breeding 
Institute, Cobbitty. In Australia, seedlings were raised in 90-mm pots (four lines per pot), containing a mixture of pine bark fines and coarse sand. A soluble nitrogenous fertilizer (Aquasol; Hortico Pty. Ltd.) was applied at a rate of 35 g per 3 liters for 100 pots prior to sowing. Seedlings were raised in a disease-free growth room in the greenhouse, where temperatures were maintained from 17 to $20^{\circ} \mathrm{C}$. The Australian stem rust differential genotypes (21) were also sown, with five lines per pot, consisting of approximately 10 seeds per line. These were supplemented with eight barley genotypes ('Chevron', '80-TT-29', '80-tt-30', 'Hietpas-5', '119Y4', Q21861, 'O'Connor', and 'Steptoe') (Table 1) that were selected based on their response against Australian $P$. graminis f. sp. tritici pathotype P6L25. Chevron is the original source of Rpg1 (34). Lines '80-TT-29' (Rpgl+) and '80-tt-30' (Rpgl-) are nearisogenic for the presence and absence, respectively, of Rpgl (41). These were included to assess the reaction of the Rpgl allele with- out the influence of major genetic background differences. Hietpas-5 is the source of Rpg2 (28). 119Y4 is a recombinant $H$. vulgare line with three distal $H$. bulbosum introgressions that was shown to possess resistance to pathotype QCCJ (10), and is highly resistant to Australian stem rust pathotypes (L. Derevnina, D. Singh, P. Zhang, H. Karaoglu, and R. F. P. Park, unpublished). Q21861 carries Rpgl, rpg4, and Rpg5, and was shown to be highly resistant to all pathotypes of $P$. graminis f. sp. tritici, including "Ug99" (38). O'Connor was shown to be highly resistant in tests using many Australian $P$. graminis f. sp. tritici pathotypes (R. F. Park, unpublished). Steptoe is a susceptible control and does not possess any known genes for stem rust resistance. Seed of 'PI 382313' (Rpg3; 12), Peatland $(R p g U ; 11)$, and Black Hulless $(R p h B H ; 42)$ were not available for experiments conducted in Australia.

For seedling tests conducted at the Cereal Research Centre (CRC) in Winnipeg, Manitoba, Canada, 5 to 7 seeds were sown per

Table 1. Infection type response of 87 barley genotypes inoculated with Puccinia graminis f. sp. tritici pathotype 98-1,2,3,5,6 and incubated at two temperatures $^{\mathrm{a}}$

\begin{tabular}{|c|c|c|c|c|c|}
\hline Barley genotype & Low & High & Barley genotype & Low & High \\
\hline Chevron $^{\mathrm{b}}$ & $2^{+} 2$ & 21 & Kaputar & $2+2$ & 221 \\
\hline Hietpas $5^{\mathrm{b}}$ & $12^{+}$ & $23^{-1}$ & Keel & $1^{+} 12$ & $1+2$ \\
\hline Q21861 ${ }^{\mathrm{b}}$ & 0 & $0 ;^{\mathrm{n}}$ & Ketch & $22^{+}$ & $3=2$ \\
\hline Steptoe ${ }^{b}$ & $213=$ & $2^{+} 2$ & Lara & $1+2$ & $1^{+} 22^{+}$ \\
\hline $80-\mathrm{TT}-29^{\mathrm{b}}$ & $22^{+}$ & $1^{+} 2^{-}$ & Lindwall & $3=2$ & $3=2$ \\
\hline $80-\mathrm{tt}-30^{\mathrm{b}}$ & $22^{+}$ & $22^{+}$ & Lockyer & $3=2$ & $2^{+} 2$ \\
\hline $1194^{b}$ & $;^{\mathrm{n}}$ & $2^{++}$ & Mackay & $22^{+}$ & $2^{+} 2$ \\
\hline Arapiles & $22^{+}$ & $23^{-1}$ & Maritime & $2+23$ & $2+23$ \\
\hline Bandulla & $21 ;$ c & $21 ; c^{c}$ & Malebo & $23=$ & $2-2$ \\
\hline Barque & $12^{=\mathrm{c}}$ & $21^{c}$ & Milby & $2^{+} 2$ & $2^{+} 2 c$ \\
\hline Baudin & $2^{++} 3$ & $2+3=$ & Molloy & 21; & $2^{+} 2$ \\
\hline Beecher & $12^{-\mathrm{cn}}$ & 21 & Moondyne & $1^{+}$ & $1+2$ \\
\hline Binalong & $10 ; 2$ & $1^{+} 2$ & Mundah & $1^{++2}$ & $1^{+} 2$ \\
\hline Brindabella & $2^{+} 2$ & $2^{+} 2$ & $\mathrm{O}^{\prime}$ Connor ${ }^{\mathrm{b}}$ & $0 n^{\mathrm{n}}$ & 0 \\
\hline Buloke & $12^{-}$ & 20 & Onslow & $22^{+}$ & - \\
\hline Bussell & $1^{+\mathrm{cn}}$ & $1^{+c n}$ & Pacific Ranger & $0 ; 1$ & $0 ; 1$ \\
\hline Capstan & $2^{+} 2$ & $2^{+} 2$ & Parwan & $1 ; 2$ & $1^{+} 2$ \\
\hline Cask & $0 ; 12$ & $2^{+} 1$ & Prior & $11^{+}$ & $11^{+} 2$ \\
\hline Chebec & $1^{+} 1 ; 2^{-}$ & $1^{+} 12$ & Picola & $22+3$ & 213; \\
\hline Chieftain & $2+2$ & $2+2$ & Quasar & $11^{+}$ & $1^{+} 1^{\text {cn }}$ \\
\hline Clipper & $22^{+} 3^{-}$ & $2^{+} 3$ & Quickstar & $1 ; 0^{\mathrm{cn}}$ & $11^{+} 2$ \\
\hline Commander & $10 ; 2=$ & $11^{+} 2$ & Roe & $3=2$ & $3=21$ \\
\hline Corvette & $22^{+}$ & $22^{+} 3$ & Schooner & $3=21$ & $3=21$ \\
\hline Cosmic & $0 ; 12$ & $; 12$ & Shannon & $3=2$ & $3=2$ \\
\hline Cowabbie & $22^{+}$ & $22^{+}$ & Shepherd & $1^{+} 12$ & $1^{+} 2$ \\
\hline Cutter & $11^{+}$ & $22^{+}$ & Skiff & $3=2$ & $3=2+2$ \\
\hline Dash & $;^{+\mathrm{cn}}$ & $1^{+} 22^{+}$ & Sloop & $2^{+} 2 n$ & $2^{+} 2$ \\
\hline Dhow & $3=2$ & $3=2^{+}$ & Sloop Vic & $2+2 c$ & $22^{+}$ \\
\hline Dictator & $3-2$ & $2+2$ & Starmalt & $11^{+}$ & $21^{+}$ \\
\hline Doolup & $; 1^{++}$ & $3^{-2}$ & Stirling & $2^{+} 23$ & $; 12^{\mathrm{c}}$ \\
\hline Empress & $2^{+} 3$ & $2^{+} 3$ & Tallon & $22^{+}$ & $22^{+}$ \\
\hline Fitzgerald & $2+2$ & 21 & Tantangara & $2=1$ & 213 \\
\hline Fitzroy & $2^{+} 2$ & $2^{+} 2$ & Tilga & $22^{+}$ & $22^{+}$ \\
\hline Flagship & $21^{\mathrm{cn}}$ & $21^{\mathrm{c}}$ & Torrens & 210 & $2^{=}$ \\
\hline Fleet & $3=2$ & $3=2$ & Tulla & $22^{+}$ & $22^{+}$ \\
\hline Franklin & 123 & 123 & Ulandra & $22^{+}$ & $1^{+} 2^{\mathrm{cn}}$ \\
\hline Gairdner & $2^{+} 2$ & $2^{+} 23$ & Unicorn & $1 ; 2$ & $2^{+} 2$ \\
\hline Galaxy & $32^{+}$ & $32^{+}$ & Vertess & $11^{+} 2$ & 12 \\
\hline Galleon & $2^{+} 2$ & $2+2$ & Vlamingh & $2^{+} 23$ & $2^{+} 23$ \\
\hline Gilbert & $2+2$ & $12^{\mathrm{cn}}$ & Weeah & $11^{+2}$ & $1^{+} 2^{\mathrm{cn}}$ \\
\hline Grimmett & $2^{+} 3^{=}$ & $2^{+} 3^{=}$ & Westminster & $11^{+} 2$ & $11^{+} 2$ \\
\hline Grout & $32+2$ & $32^{+}$ & Windich & $12 \cdot \mathrm{cn}$ & $12 \mathrm{c}^{\mathrm{c}}$ \\
\hline Gus & 21 & 21 & Wyalong & $1 ; 2$ & $22^{+}$ \\
\hline Hamelin & $1+2$ & $11^{+2}$ & Yagan & $22+3$ & $22^{+}$ \\
\hline Hannan & $22^{+} 1$ & $22+3$ & Yambla & $22^{+}$ & $22^{+}$ \\
\hline Harrington & 321 & 312 & Yarra & $22^{+}$ & $22^{+}$ \\
\hline Hindmarsh & $2^{+} 2$ & $22+3$ & Yerong & $22^{+}$ & 321 \\
\hline
\end{tabular}

${ }^{a}$ Barley seedlings were scored using a modified 0-to-4 infection type (IT) scale, based primarily on uredinial size (20,21). The ITs recorded, therefore, indicate the most common pustule, followed by the next most common pustule, where IT $0=$ no visible symptoms, $;=$ hypersensitive flecks, $1=$ minute uredinia surrounded by mainly necrotic tissue, $2=$ small to medium-sized uredinia surrounded by chlorotic or necrotic tissue, $3=$ medium to large uredinia with or without surrounding chlorosis, and $4=$ large uredinia without chlorosis. The letters ' $c$ ' and ' $n$ ' indicate greater than normal chlorosis or necrosis, respectively; '-' or ' + ' indicate lower or higher infection types than normal, respectively. Infection types of $3+$ or higher were considered to indicate compatibility (i.e., virulent pathogen/susceptible host). Low $=$ low temperature $\left(16\right.$ to $\left.20^{\circ} \mathrm{C}\right)$ and $\mathrm{High}=$ high temperature $\left(23\right.$ to $\left.27^{\circ} \mathrm{C}\right)$.

b Australian barley stem rust differential genotypes. 
line in plastic cones (20 cm deep and $4 \mathrm{~cm}$ in diameter) containing Sunshine mix number 5 (Sun Gro Horticulture Inc.). Water-soluble fertilizer (Peters 15-0-15, N-P-K, stock solution concentration of $45 \mathrm{~g} /$ liter, 435 to $535 \mathrm{ppm}$ per container) was added at planting to neutralize the $\mathrm{pH}$. Australian barley differential genotypes were supplemented with 'GAW-79' ('PI 382313'), 'Black Hulless', and '212Y1', the source of rpg6 (10).

Pathogen isolates. Greenhouse inoculations were carried out in Australia using P. graminis pathotype 98-1,2,3,5,6 (accession number 781219). Lines carrying Rpg1, based on marker analyses, were tested in Canada using North American pathotypes MCCJ (1541), QCCJ (1540), SPMK (973), TTTT (1349), HFCJ (1382), and HKCJ (1176). MCCJ, TTTT, HFCJ, and HKCJ are avirulent on Rpg1, while QCCJ and SPMK are virulent on Rpg1. 'O'Connor' was included because it showed a high level of resistance to $P$. graminis $\mathrm{f}$. sp. tritici in Australia under greenhouse conditions, and 'Franklin' was included because it was a parent in the doubled-haploid (DH) population. All tests were replicated. The Australian stem rust pathotype is defined by its response on the Stakman differentials (e.g., race 98) and 13 supplementary differentials (e.g., -1,2,3,5,6) (21). The four-letter code of the North American pathotypes represents the reaction of each stem rust pathotype across 16 standard differential genotypes (32). Pathotypes MCCJ and QCCJ were used to assay for the presence of $R p g 1$ and $r p g 4$, respectively.

Inoculation procedures. Greenhouse inoculations were carried out on 8- to 10-day-old seedlings with fully expanded first leaves.
Seedlings were heavily inoculated and the differential genotypes were used to determine the success of the inoculation. In Australia, urediniospores were suspended in light mineral oil (Isopar; Univar) and applied on the leaves at a rate of approximately $10 \mathrm{mg}$ of spores per $10 \mathrm{ml}$ oil per 200 pots, using a hydrocarbon propellant pressure pack. Seedlings were incubated in trays of water under polyethylene hoods for $48 \mathrm{~h}$. In Canada, urediniospores were applied on leaves at the rate of $4 \mathrm{mg}$ of urediniospores per $0.7 \mathrm{ml}$ of Bayol oil (ESSO, Canada). Seedlings were incubated in mist chambers at $21^{\circ} \mathrm{C}$ for $16 \mathrm{~h}$ in darkness. Mist was generated by an ultrasonic humidifier. After incubation, seedlings were transferred to microclimate rooms where temperatures were maintained at either 16 to $20^{\circ} \mathrm{C}$ (low) or 23 to $27^{\circ} \mathrm{C}$ (high).

Disease assessment. Seedlings were assessed for stem rust response 14 to 16 days after inoculation for lines maintained between 16 to $20^{\circ} \mathrm{C}$, and 10 to 12 days postinoculation for lines maintained between 23 and $27^{\circ} \mathrm{C}$, using a 0-to-4 infection type scale (22). Variation in infection type were indicated by the use of '-' (less than average for the class), '+' (more than average for the class), 'c' (chlorosis), or ' $n$ ' (necrosis). The seedling reaction of barley to $P$. graminis f. sp. tritici is not as distinct as is observed in wheat. It is frequently associated with chlorosis and typically extends over a more limited range within a typical ' $\mathrm{X}$ ' or mesothetic reaction (with leaves exhibiting a range of pustule types; 28); therefore, using the standard 0-to-4 infection type scale (21) is difficult. The current scoring method for barley is based on uredinial size (22)

Table 2. Description of markers used to assess 87 barley cultivars for the presence and absence of the Rpg1 and Rpg5 genes

\begin{tabular}{|c|c|c|c|}
\hline Marker name & Sequence $\left(5^{\prime}-3^{\prime}\right)^{\mathrm{a}}$ & Size (bp) & Annealing temperature $\left({ }^{\circ} \mathbf{C}\right)$ \\
\hline \multirow[t]{2}{*}{ RPG1R $^{\mathrm{b}}$} & F:CGGCTAATCACATCAAGTAA & 610 & 51 to 66 \\
\hline & R:TTCTCCATTGTCCAACA*CTC & & \\
\hline \multirow[t]{2}{*}{ RPG1-N } & $\mathbf{F}:$ CGGCTAATCACATCAAGTAA ${ }^{\mathrm{b}}$ & 669 & 61 \\
\hline & R:AGCCCATCATCAATAGACAA ${ }^{c}$ & & \\
\hline \multirow[t]{2}{*}{ RPG1-S ${ }^{b}$} & F:GGCTAATCACATCAAGGTT & 487 & 57 \\
\hline & R:CCACGACCAATTATGTTCTG & & $\ldots$ \\
\hline \multirow[t]{2}{*}{ Rpg5-LRK } & F:CTGCTGGCACAGAGTCTGCCTTGAG & 1,046 & 62 \\
\hline & R:ACTCTCGGGTCTGAAGTTCCGTGTG & & \\
\hline \multirow[t]{2}{*}{ Rpg5-LRK/PP2C } & F:CTGCTGGCACAGAGTCTGCCTTGAG & 840 & 62 \\
\hline & R:CCCGAGGTTTGCGATGAAGAGAGTC & $\ldots$ & $\ldots$ \\
\hline
\end{tabular}

${ }^{a}$ Asterisk $(*)$ indicates a missing nucleotide base from the published sequence.

${ }^{b}$ Reference: Dill-Macky et al. (8).

${ }^{\mathrm{c}}$ Reference: Dellaporta et al. (5).

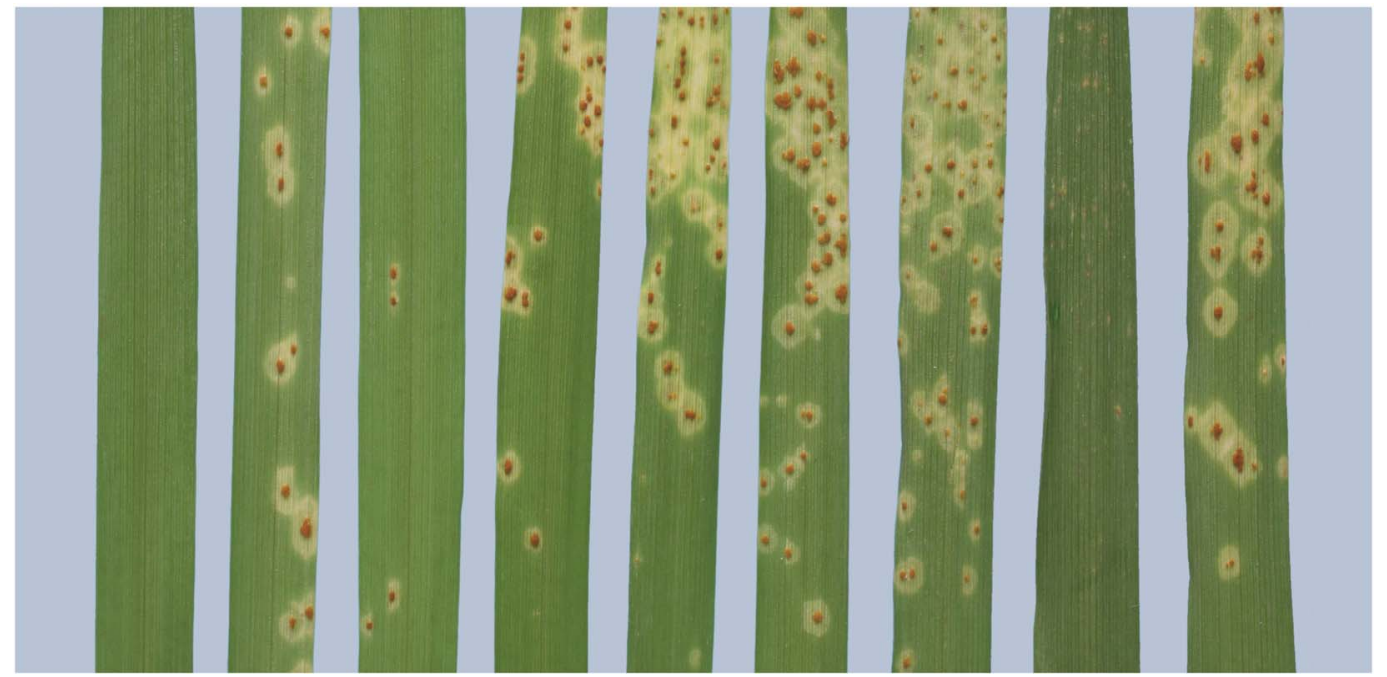

Fig. 1. Reaction of barley cultivars to Puccinia graminis $\mathrm{f}$. sp. tritici pathotype $98-1,2,3,5,6$ when incubated at $25^{\circ} \mathrm{C}$. From left to right: 'O'Connor' infection type (IT) $0 ; 1$, 'Empress' IT 2+3, 'Pacific Ranger' IT 0;1, 'Vlamingh' IT 2+2, 'Franklin' IT 123, 'Yerong' IT 32-, 'Chevron' IT 21;, 'Q21861' IT 0;" and 'Steptoe' IT 2+23. Barley seedlings were scored using a modified 0-to-4 IT scale, based primarily on uredinial size $(20,21)$. The ITs recorded, therefore, indicate the most common pustule, followed by the next most common pustule, where IT $0=$ no visible symptoms, ; = hypersensitive flecks, $1=$ minute uredinia surrounded by mainly necrotic tissue, $2=$ small to medium-sized uredinia surrounded by chlorotic - necrotic tissue, $3=$ medium to large uredinia with or without surrounding chlorosis, and $4=$ large uredinia without chlorosis. The letters ' $c$ ' and ' $n$ ' indicate greater than normal chlorosis or necrosis, respectively; '-' or '+' indicate lower or higher infection types than normal, respectively. Infection types of $3+$ or higher were considered to indicate compatibility (i.e., virulent pathogen/susceptible host). 
and involves recording the observed infection types in order of prevalence (39). Lines that exhibited infection types of 0,$0 ; 1$, and

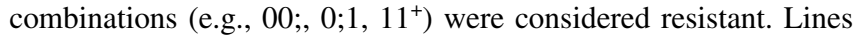
that exhibited infection types of 3 and combinations (e.g., $3^{-2}$ and $33^{+}$) were considered susceptible.

Molecular marker analysis. Barley stem rust resistance genes Rpg1 and Rpg5 have been cloned $(3,4)$ and perfect markers are available to detect the presence of these genes. Genomic DNA was extracted directly from dried leaf tissue from five leaves (14 days old, roughly $500 \mathrm{mg}$ ) of each barley line, using a modified sodium dodecyl sulfate (SDS) method outlined by Dellaporta et al. (5). Extraction buffer $(750 \mu \mathrm{l}$ of $50 \mathrm{mM}$ Tris- $\mathrm{HCl}, 10 \mathrm{mM}$ EDTA, 100 $\mathrm{mM} \mathrm{NaCl}, 1 \%$ [wt/vol] SDS, and $10 \mathrm{mM} \beta$-mercaptoethanol, $\mathrm{pH}$ 8.0) prewarmed to $65^{\circ} \mathrm{C}$, was added to each tube. Samples were incubated $\left(65^{\circ} \mathrm{C}\right)$ for $10 \mathrm{~min}$ and tubes were inverted every 2 to 3 min. $3 \mathrm{M}$ potassium acetate $(150 \mu \mathrm{l}, \mathrm{pH} 5.2)$ was added in each tube and mixed by gentle inversion. Tubes were stored at $-20^{\circ} \mathrm{C}$ for 20 min and centrifuged at $17,900 \times g$ for $20 \mathrm{~min}$. The supernatant was transferred to a new 2-ml tube and an equal volume of isopropanol (stored at $-20^{\circ} \mathrm{C}$ ) was added. The tubes were then centrifuged at $10,600 \times g$ for $10 \mathrm{~min}$. The pellet was washed with $500 \mu \mathrm{l}$ of $70 \%$ (wt/vol) ethanol and air dried before being resuspended in $200 \mu \mathrm{l}$ of double-distilled $\mathrm{H}_{2} \mathrm{O}$ and stored at $4{ }^{\circ} \mathrm{C}$ overnight. The tubes were then centrifuged at $10,600 \times g$ for 5 min, and the supernatant was transferred into a fresh tube and stored at $-20^{\circ} \mathrm{C}$. The concentration of DNA was determined using a spectrophotometer (NanoDrop; BioLab) and adjusted to a final concentration of $25 \mathrm{ng} / \mu \mathrm{l}$. RNA was removed by adding 10 $\mu \mathrm{l}$ of RNase A (10 $\mathrm{ng} / \mu \mathrm{l})$.

Polymerase chain reaction (PCR) amplifications were performed in an automated thermocycler (MasterCycler; Eppendorf) using 96-well plates (Astral Scientific). Thirty-five cycles were conducted in each assay, consisting of the following profiles' anneal temperature and primer sequence information are provided in Table 2. For RPG1R and RPG1S: denaturation at $94^{\circ} \mathrm{C}$ for $45 \mathrm{~s}$, anneal for $45 \mathrm{~s}$, and extension at $72^{\circ} \mathrm{C}$ for $60 \mathrm{~s}$. For RPG1-N: denaturation at $94^{\circ} \mathrm{C}$ for $30 \mathrm{~s}$, anneal for $45 \mathrm{~s}$, and extension at $72^{\circ} \mathrm{C}$ for $60 \mathrm{~s}$. For Rpg5-LRK and Rpg5-LRK/PP2C: denaturation at $94^{\circ} \mathrm{C}$ for $30 \mathrm{~s}$, anneal for $60 \mathrm{~s}$, and extension at $72^{\circ} \mathrm{C}$ for $60 \mathrm{~s}$. PCR amplifications were performed in a final volume of $15 \mu \mathrm{l}$ and contained $25 \mathrm{ng}$ of template DNA, $0.75 \mathrm{U}$ of $\mathrm{Taq}$ polymerase (Applied Biosystems), $1.5 \mu \mathrm{l}$ of $10 \times$ buffer (Applied Biosystems), $1.5 \mu \mathrm{l}$ of $2.0 \mathrm{mM}$ dNTPs, $0.9 \mu \mathrm{l}$ of both forward and reverse primer sequences (at 10 $\mathrm{ng} / \mu \mathrm{l})$, and $0.9 \mu \mathrm{l}$ of $2.0 \mathrm{mM} \mathrm{MgCl}{ }_{2}$.

Products were loaded with buffer $(98 \%$ formamide, $10 \mathrm{mM}$ EDTA at $\mathrm{pH} 8.0,0.05 \%$ [wt/vol] bromophenol blue, and $0.05 \%$ xylene cyanol) into a 3\% agarose gel (Agarose I; Amresco), prepared in $1 \times$ Tris-borate EDTA buffer $(90 \mathrm{mM}$ Tris-borate $+2 \mathrm{mM}$ EDTA at $\mathrm{pH}$ 8.0), and subjected to electrophoresis at $100 \mathrm{~V}$ for 1.5 h. The separated products were stained with GelRed and visualized under ultraviolet light (GelDoc IT imaging System, Model M-26; BioImaging Systems). All images were captured in QCapture 2.66.4 (Q Cam driver DLL version 1.68; Quantitative Imaging Corporation).

Reactions using the RPG1-R marker failed to amplify a product in the resistant controls. Selected Rpgl+ clone sequences from 'Peatland', 'Kindred', 'Leger', 'Chevron', 'Bowman', '80-TT-29', 'Q21861', and 'Morex' and Rpg1-clone sequences from 'Steptoe', 'Lion', 'Wisconsin 38', and 'Moravian III' were obtained from the Grain Genes 2.0 website, and a multiple sequence alignment was performed in the program BioEdit (version 7.0.4.0). The forward sequence published by Eckstein et al. (8) was identified straddling a 3-bp (GTT) insertion, present in susceptible but absent in resistant lines. The reverse primer sequence, however, was not located. Subsequent investigation revealed that a nucleotide base ('A') was absent from the published primer sequence, the corresponding sequence in the genomic clones was as follows: 5' GAG *TGT TGG ACA ATG GAG AA $3^{\prime}$. Prior to discovering the missing base, an amended reverse primer sequence had been developed, using the OLIGO Primer analysis software (version 7.0). The PCR reaction (RPG1-N) produced a single band at $669 \mathrm{bp}$ in coupling with resistance.

The Rpg5-specific primers were designed based on the putative translocation, insertion deletion (indel) event, which replaces the serine/threonine protein kinase (S/TPK) domain required for a functional Rpg5 gene with a putative functional protein phosphatase $2 \mathrm{C}$ gene (2). This translocated indel DNA resulting in the $\mathrm{STP} / \mathrm{K}$ to PP2C domain swap present in the majority of susceptible varieties results in a nonfunctional rpg 5 allele. It was recently determined that this is the major polymorphism resulting in the loss of rpg4-mediated resistance, and Rpg5 is the resistance gene required for $r p g 4$-mediated resistance against the wheat stem rust pathotypes QCCJ and TTKSK (1). The Rpg5-LRK primers were designed to specifically amplify a 1,046-bp fragment of genomic DNA of the functional Rpg5 gene (GenBank EU878778.1) spanning intron 2. The region amplified from exon 2 and 3 is predicted to encode the leucine-rich repeat (LRR) to S/TPK domain junction. The Rpg5-LRK/PP2C primers were designed to specifically amplify a 840-bp fragment of genomic DNA spanning from the LRR to the translocated indel region containing the PP2C domain (GenBank EU12563.1). This region of genomic DNA is specific to the majority of susceptible genotypes.

Inheritance study. The inheritance of Rpgl was studied by screening a DH population developed from the cross 'Yerong'(+Rpg1)/'Franklin'(-Rpg1) with the RPG1-N marker. The population was also tested with pathotype MCCJ and 98-1,2,3,5,6 The $\chi^{2}$ tests were used to test the hypothesis of independent segregation and to determine the goodness of fit of observed frequencies to expected ratios.

\section{Results}

Reaction of barley cultivars to $P$. graminis f. sp. tritici pathotype 98-1,2,3,5,6. The infection types of barley cultivars ranged from 0 ; to $3^{-2}$ (Fig. 1; Table 1). Most barley cultivars exhibited mesothetic reactions with pustules associated with a high level of chlorosis. Ten cultivars ('Dhow', 'Fleet', 'Galaxy', 'Grout', 'Harrington', 'Lindwall', 'Roe', 'Schooner', 'Shannon', and 'Skiff') were susceptible to pathotype 98-1,2,3,5,6, while six ('Baudin', 'Clipper', 'Empress', 'Grimmett', 'Maritime', and 'Vlamingh') displayed moderate susceptibility (intermediate reactions). The susceptible check lines Steptoe and 80 -tt-30 produced intermediate infection types. 'O'Connor', 'Pacific Ranger', and 'Q21861' produced very low reactions (infection types $0 ; 0 ; 1$, and $0 ;-0 ;{ }^{\text {n }}$, respectively) at both temperatures that were easily identified and highly reproducible. 'Binalong', 'Bussell', 'Chebec', 'Commander', 'Cosmic', 'Moondyne', 'Prior', 'Quasar', 'Quickstar', 'Shepherd', and 'Windich' displayed moderate resistant reactions to pathotype $98-1,2,3,4,5,6$ at both temperature regimes. Stem rust resistance in barley genotype 119Y4 was temperature sensitive, producing an infection type of ;n at low temperature and of $2^{++}$at higher temperatures. Resistance in 'Doolup' also appeared to be temperature sensitive, with an infection type of $; 1^{++}$at 16 to $20^{\circ} \mathrm{C}$ and $3^{-} 2$ at 23 to $27^{\circ} \mathrm{C}$.

Marker analysis. The results for each primer pair used are presented in Table 3. Empress, Pacific Ranger, Vlamingh, and Yerong produced banding patterns identical to the positive controls (Chevron, 80-TT-29, and Q21861) for the presence of Rpg1 (Supplementary Figure S1; Table 3). Thus, these four lines were hypothesized to carry Rpg1. 'Cask' and 'Milby' were positive for the RPG1-S marker (Table 3), producing identical banding patterns to the susceptible control 'Steptoe'. The remaining 81 lines, including control line Harrington, did not test positive for either the Rpgl gene or the RPG1-S marker and were classified into susceptible group 4 (9).

The results for the Rpg5 marker analyses were more variable. 'Arapiles', 'Fleet', 'Grimmett', and 'Hamelin' were positive for both the Rpg5-LRK and Rpg5-LRK/PP2C markers, suggesting that they are heterogeneous (Table 3). There were 34 lines that were positive for the Rpg5-LRK/PP2C marker only, indicating the absence of a functional Rpg5 gene. Fourteen lines did not amplify 
for either marker, suggesting that the protein structures governing resistance (nucleotide-binding site LRR and STP/K) and susceptibility (PP2C) were not present or were highly diverged in these cultivars (2). The remaining 33 lines were positive for the Rpg5-LRK marker only similar to the resistant control Q21861, suggesting a functional Rpg5 gene. However, none exhibited an infection type reaction (0;) comparable with Q21861 (Table 1).

Multipathotype tests. 'Empress', 'Pacific Ranger', 'Vlamingh', and 'Yerong' all displayed resistant infection type reactions to pathotypes MCCJ, TTTT, HFCJ, and HKCJ, and susceptible infection type reactions to QCCJ and SPMK (except 'Pacific Ranger') when incubated at high temperature (Table 4; Fig. 2). A similar infection type pattern was observed at the low incubation temperature, with the exception of 'Empress', which had an intermediate infection type to pathotypes TTTT and HKCJ (Table 4). The infection type patterns observed across these cultivars were similar to that observed in the Rpg1 check line '80-TT-29', and all were temperature insensitive (Table 4). Although the susceptible check 'Steptoe' exhibited high reactions against all races tested (particularly at 23 to $27^{\circ} \mathrm{C}$ ), line 80 -tt-30 exhibited variable responses against some of these isolates.

In contrast, 'Franklin' and 'O'Connor' displayed infection type responses that were not indicative of Rpgl (Table 4). 'Franklin' displayed intermediate infection types to all pathotypes and resistance did not appear to be temperature sensitive. 'O'Connor' displayed very low infection types to all races at low temperatures but was intermediate to pathotypes QCCJ and TTTT at high temperature (Table 4).

Inheritance studies. The Yerong/Franklin DH population segregated 107 resistant genotypes:44 susceptible genotypes $\left(\chi_{1: 1}^{2}=\right.$ 26.29, $\left.P_{1 \text { d.f. }}<0.001\right)$, which deviated significantly from the expected 1:1 ratio (Table 5). When the same population was tested with $P$. graminis f. sp. tritici pathotype MCCJ, a ratio of 119 resistant:32 susceptible was observed, indicating that there were potentially two independent genes for resistance segregating within the population $\left(\chi_{3: 1}^{2}=1.17, P_{1 \text { d.f. }}=0.28\right)$ (Fig. 3 ). Twenty-two lines were more resistant than either parent (infection types of $0^{\mathrm{n}}$ to ;). Differences in resistant infection type reactions across the population enabled a segregation ratio of $1 \mathrm{AABB}: 1 \mathrm{AAbb}$ : 1aaBB:1aabb to be tested, where AA represents the gene in Yerong $($ Rpgl) and $\mathrm{BB}$ represents another resistance gene in Franklin. The population segregated 22AABB:73AAbb:24aaBB:32aabb $\left(\chi^{2}\right.$ 1:1:1:1 $\left.=45.37, P_{3 \text { d.f. }}<0.001\right)$ and significantly deviated from the expected model (data not presented). Eleven lines were positive for the RPG1-N marker but had disease ratings that were higher than $0 ; 1$. The Yerong/Franklin DH population was also tested with

Table 3. Molecular marker results of four primer sets used to determine the presence and absence of Rpg1 and Rpg ${ }^{\text {a }}$

\begin{tabular}{|c|c|c|c|c|c|c|c|c|c|}
\hline \multirow[b]{2}{*}{ Barley } & \multicolumn{4}{|c|}{ Marker analysis } & \multirow[b]{2}{*}{ Barley } & \multicolumn{4}{|c|}{ Marker analysis } \\
\hline & RPG1-N & RPG1-S & Rpg5-LRK/PP2C & Rpg5-LRK & & RPG1-N & RPG1-S & Rpg5-LRK/PP2C & Rpg5-LRK \\
\hline Arapiles & - & - & + & + & Maritime & - & - & + & - \\
\hline Bandulla & - & - & - & + & Malebo & - & - & + & - \\
\hline Barque & - & - & - & + & Milby & - & + & - & + \\
\hline Baudin & - & - & - & + & Molloy & - & - & + & - \\
\hline Beecher & - & - & - & - & Moondyne & - & - & + & - \\
\hline Binalong & - & - & + & - & Mundah & - & - & - & - \\
\hline Brindabella & - & - & - & + & O'Connor & - & - & + & - \\
\hline Buloke & - & - & - & + & Onslow & - & - & - & - \\
\hline Bussell & - & - & + & - & Pacific Ranger & + & - & + & - \\
\hline Capstan & - & - & - & + & Parwan & - & - & - & + \\
\hline Cask & - & + & - & + & Prior & - & - & - & + \\
\hline Chebec & - & - & - & + & Picola & - & - & - & + \\
\hline Chieftain & - & - & - & - & Quasar & - & - & + & - \\
\hline Clipper & - & - & - & + & Quickstar & - & - & + & - \\
\hline Corvette & - & - & - & + & Roe & - & - & - & - \\
\hline Cosmic & - & - & + & - & Schooner & - & - & - & + \\
\hline Cowabbie & - & - & - & + & Shannon & - & - & - & + \\
\hline Cutter & - & - & - & + & Skiff & - & - & + & - \\
\hline Dash & - & - & - & - & Sloop & - & - & - & + \\
\hline Dhow & - & - & + & - & Sloop Vic & - & - & - & + \\
\hline Dictator & - & - & - & - & Starmalt & - & - & - & - \\
\hline Doolup & - & - & + & - & Stirling & - & - & - & + \\
\hline Empress & + & - & + & - & Tallon & - & - & - & + \\
\hline Fitzgerald & - & - & - & - & Tantangara & - & - & + & - \\
\hline Fitzroy & - & - & - & - & Tilga & - & - & + & - \\
\hline Flagship & - & - & - & + & Torrens & - & - & + & - \\
\hline Fleet & - & - & + & + & Tulla & - & - & + & - \\
\hline Franklin & - & - & - & + & Ulandra & - & - & + & - \\
\hline Gairdner & - & - & - & - & Unicorn & - & - & + & - \\
\hline Galaxy & - & - & - & + & Vertess & - & - & - & + \\
\hline Galleon & - & - & - & + & Vlamingh & + & - & + & - \\
\hline Gilbert & - & - & - & + & Weeah & - & - & - & + \\
\hline Grimmett & - & - & + & + & Windich & - & - & + & - \\
\hline Grout & - & - & - & + & Wyalong & - & - & - & + \\
\hline Hamelin & - & - & + & + & Yagan & - & - & - & - \\
\hline Hannan & - & - & - & + & Yambla & - & - & + & - \\
\hline Harrington & - & - & + & - & Yarra & - & - & + & - \\
\hline Hindmarsh & - & - & + & - & Yerong & + & - & + & - \\
\hline Kaputar & - & - & + & - & Shephard & - & - & - & + \\
\hline Keel & - & - & + & - & Commander & - & - & - & - \\
\hline Ketch & - & - & + & - & Gus & - & - & + & - \\
\hline Lara & - & - & + & - & Westminster & - & - & $*$ & $*$ \\
\hline Lindwall & - & - & + & - & Q21861 & + & - & - & + \\
\hline Lockyer & - & - & - & - & Steptoe & - & + & + & - \\
\hline Mackay & - & - & - & + & $\ldots$ & $\ldots$ & $\ldots$ & $\ldots$ & $\ldots$ \\
\hline
\end{tabular}

a Barley = barley genotype; '+' and' '-' indicate a positive and negative polymerase chain reaction, respectively; and $*$ indicates data not available. 
pathotype 98-1,2,3,5,6. The population segregated 66 resistant:85 susceptible $\left(\chi^{2}=2.39, P_{1 \text { d.f. }}=0.12\right)$ for resistance observed in 'Franklin' (21;) (Table 5).

\section{Discussion}

Several Australian barley genotypes with effective levels of stem rust resistance at the seedling stage were identified in this study. Prior displayed resistant infection type reactions at both low and high incubation temperatures to pathotype 98-1,2,3,5,6. Tests of allelism revealed that resistance in Prior was not governed by the Rpg1 gene (8). Prior is derived from European 'Archer' and 'Chavalier' and was first released in 1905. Since that time, it has been widely used in breeding programs and is found in the pedigrees of many Australian cultivars (27). In fact 'Bandulla', 'Bussell', 'Moondyne', 'O'Connor', 'Parwan', 'Weeah', and 'Windich' were all directly derived from 'Prior'. Because these cultivars produced low mesothetic reactions at the seedling stage, it is possible that the resistance in these lines originated from Prior. Because ' $O$ 'Connor' $(0 ;)$ was highly resistant to all stem rust pathotypes tested, it may carry an additional gene which is not Rpg1, rpg4, or Rpg5. The long-standing effectiveness of the 'Prior' resistance in Australia led Dill-Macky (7) to speculate that it might be durable. Therefore, further studies should be undertaken to characterize this resistance, including tests of allelism and studies of inheritance.

Several other accessions ('Binalong', 'Chebec', 'Commander', 'Cosmic', 'Hamelin', 'Keel', 'Quasar', 'Quickstar', and 'Shepherd') also displayed seedling resistance to pathotype 98-1,2,3,5,6. 'Cosmic' and 'Quickstar' are of unknown pedigree, 'Binalong' is derived from 'O'Connor', 'Commander' is derived from 'Keel', and the origin of the resistances observed in 'Chebec', 'Hamelin', 'Quasar', and 'Shepherd' are unknown. Although the field reactions of these lines to $P$. graminis f. sp. tritici have not been determined, studies to characterize the inheritance of resistance are worthwhile in these lines because they show promising resistance to pathotype $98-1,2,3,5,6$.

This study clearly showed that some pathotypes were much better at distinguishing known Rpg genes than others. Accessions known to carry Rpgl ('80-TT-29' and 'Chevron') or shown to carry Rpgl by marker analyses ('Empress', 'Vlamingh', 'Pacific Ranger', and 'Yerong') exhibited intermediate to high infection

Table 4. Infection types (ITs) of barley cultivars in response to six North American pathotypes of Puccinia graminis f. sp. tritici, incubated at low (16 to $\left.20^{\circ} \mathrm{C}\right)$ and high $\left(23\right.$ to $\left.27^{\circ} \mathrm{C}\right)$ temperatures ${ }^{\mathrm{a}}$

\begin{tabular}{|c|c|c|c|c|c|c|c|c|c|c|c|c|c|}
\hline \multirow[b]{2}{*}{ Accession } & \multirow[b]{2}{*}{ Resistance $^{\mathrm{b}}$} & \multicolumn{2}{|c|}{ MCCJ } & \multicolumn{2}{|c|}{ QCCJ } & \multicolumn{2}{|c|}{ SPMK } & \multicolumn{2}{|c|}{ TTTT } & \multicolumn{2}{|c|}{ HFCJ } & \multicolumn{2}{|c|}{ HKCJ } \\
\hline & & Low & High & Low & High & Low & High & Low & High & Low & High & Low & High \\
\hline 80-TT-29 & Rpg1 & $\begin{array}{l}10 ; c \text { to } \\
10 ; 2^{-}\end{array}$ & $0 ; 1^{-}$ & $3^{-32}$ & $33^{+}$ & $\begin{array}{c}213^{-\mathrm{c}} \text { to } \\
3^{-2}\end{array}$ & $23^{-1}$ & $\begin{array}{l}10 ; 2^{-\mathrm{c}} \\
\text { to } 12^{\mathrm{c}}\end{array}$ & $\begin{array}{l}; 1 \text { to } \\
12^{-}\end{array}$ & $\begin{array}{c}0 ; \text { to } \\
10 ; 2^{-\mathrm{c}}\end{array}$ & $0 ; 1^{-}$ & $\begin{array}{l}10 ; \text { to } \\
10 ; 2^{-c}\end{array}$ & $\begin{array}{l}; 1 \text { to } \\
10 ;\end{array}$ \\
\hline Chevron & Rpg1 & 1 & 0 & $\begin{array}{c}10 ; 2 \text { to } \\
21\end{array}$ & $23^{-}$ & $\begin{array}{l}12^{-} \text {to } \\
21^{\mathrm{c}}\end{array}$ & $\begin{array}{c}10 ; 2 \text { to } \\
120\end{array}$ & $\begin{array}{l}0 ; \text { to } \\
0 ; 1=\end{array}$ & $1^{+}$ & 1 & 0 & $\begin{array}{l}0 ; \text { to } \\
0 ; 1=\end{array}$ & 0 \\
\hline Hietpas 5 & Rpg2 & $\begin{array}{l}3-2 \text { to } \\
3-32\end{array}$ & $\begin{array}{c}33^{-} \text {to } \\
33^{+}\end{array}$ & $\begin{array}{c}23^{-} \text {to } \\
3^{-} 2\end{array}$ & $\begin{array}{c}23^{-} \text {to } \\
3^{-2}-2\end{array}$ & $\begin{array}{c}0 ; 1 \text { to } \\
12^{-\mathrm{c}}\end{array}$ & $23^{-}$ & 0 & $23^{-}$ & $23^{-c}$ & $213^{-}$ & $\begin{array}{c}21 \text { to } \\
3^{-\mathrm{c}}\end{array}$ & 12 \\
\hline GAW-79 & Rpg3 & $\begin{array}{c}120 ; \text { to } \\
3^{-} 2^{\mathrm{c}}\end{array}$ & $\begin{array}{c}213^{-} \text {to } \\
23^{-}\end{array}$ & $\begin{array}{c}213^{-} \text {to } \\
3^{-2} 21\end{array}$ & $213^{-}$ & $\begin{array}{c}12^{-c} \text { to } \\
21\end{array}$ & $213^{-}$ & 21 & $\begin{array}{c}10 ; 2^{-} \text {to } \\
12^{-}\end{array}$ & $\begin{array}{l}0 ; \text { to } \\
12^{-\mathrm{c}}\end{array}$ & $12^{-}$to 2 & $\begin{array}{c}0 ; 1 \text { to } \\
12^{-\mathrm{c}}\end{array}$ & $\begin{array}{c}23^{-} \text {to } \\
23\end{array}$ \\
\hline Q21861 & $R p g 1+r p g 4$ & 00 & 0 & 00 & 0 & 00 & 0 & 00 & 0 & $\begin{array}{c}00 ; \text { to } \\
0 ; 1\end{array}$ & 0 & 00 & 0 \\
\hline $212 Y 1$ & rpg6 & $\begin{array}{c}00 ; \text { to } \\
0 ;\end{array}$ & 23 & $\begin{array}{l}0 ; 1 \text { to } \\
10 ; 2^{-}\end{array}$ & $33^{-}$ & $\begin{array}{l}0 ; 1 \text { to } \\
10\end{array}$ & $\begin{array}{l}2^{-} \text {to } \\
23^{-1}\end{array}$ & $\begin{array}{l}0 ; \text { to } \\
0 ; 1^{-}\end{array}$ & $\begin{array}{c}1^{+} \text {to } \\
12^{+}\end{array}$ & $\begin{array}{c}00 ; \text { to } \\
0 ;\end{array}$ & $23^{-}$ & $\begin{array}{c}0 ; 1^{-} \text {to } \\
0 ; 1\end{array}$ & 0 \\
\hline Black & & $21^{\mathrm{c}}$ to & $23^{-1} 1$ to & 12 to 21 & $213^{-}$to & $0 ; 1^{\mathrm{c}}$ to & 210 ; to & $21^{\mathrm{c}}$ to & $10 ; 2^{-}$to & 21 to & 12 to 21 & 2 & $12^{-\mathrm{c}}$ to \\
\hline Hulless & $r p g B H$ & $3^{-}$ & $2-3$ & & $23^{-\mathrm{c}}$ & $12^{-}$ & $23^{-1}$ & $2^{-}$ & $12^{-}$ & $23^{-}$ & & & $213^{-}$ \\
\hline $80-\mathrm{tt}-30$ & None & $\begin{array}{c}33^{-\mathrm{c}} \text { to } \\
3^{-32}\end{array}$ & $3^{-} 32$ & $\begin{array}{c}213^{-} \text {to } \\
3^{-2}\end{array}$ & $3-2$ & $23^{-c}$ & $\begin{array}{l}12^{-} \text {to } \\
213^{-}\end{array}$ & 0 & 21 & 0 & $\begin{array}{l}1 ; \text { to } \\
23^{-}\end{array}$ & $23^{-} 1^{\mathrm{c}}$ & $\begin{array}{c}12^{-} \text {to } \\
23^{-}\end{array}$ \\
\hline Steptoe & None & $\begin{array}{c}23^{-} 1^{\mathrm{c}} \text { to } \\
3^{-} 32^{\mathrm{c}}\end{array}$ & $\begin{array}{c}3^{-32} \text { to } \\
33^{-}\end{array}$ & $\begin{array}{c}213^{-} \text {to } \\
3^{-2}\end{array}$ & $33^{+}$ & $3-23$ & $\begin{array}{c}3^{-2} \text { to } \\
33^{+}\end{array}$ & $\begin{array}{l}21 \text { to } \\
213^{-\mathrm{c}}\end{array}$ & $\begin{array}{c}3^{-32} \text { to } \\
33^{+}\end{array}$ & $\begin{array}{c}23^{-} 1 \mathrm{c} \text { to } \\
3^{-2}\end{array}$ & $\begin{array}{c}213^{-} \text {to } \\
3^{-32}\end{array}$ & $\begin{array}{l}21 \mathrm{c} \text { to } \\
23^{-} 1\end{array}$ & $\begin{array}{c}213^{-} \text {to } \\
23^{-}\end{array}$ \\
\hline Empress & $?$ & $0 ; 1$ & $\begin{array}{l}0 ; \text { to } \\
0 ; 1^{-}\end{array}$ & $\begin{array}{l}12^{-} \text {to } \\
213^{-}\end{array}$ & $\begin{array}{l}23^{-} \text {to } \\
3^{-3} 32^{c}\end{array}$ & $\begin{array}{l}12^{-} \text {to } \\
213^{-\mathrm{c}}\end{array}$ & $3-2$ & $2^{-} \mathrm{c}$ to 2 & 0 ; to 12 & 1 & ; 1 to 21 & $\begin{array}{c}21 \text { to } \\
23^{-}\end{array}$ & $\begin{array}{c}10 ; 2^{-} \text {to } \\
21\end{array}$ \\
\hline Franklin & $?$ & $\begin{array}{l}12^{-} \text {to } \\
21^{\mathrm{c}}\end{array}$ & 12 to 21 & $\begin{array}{c}10 ; 2^{-} \text {to } \\
12\end{array}$ & $\begin{array}{c}21 \text { to } \\
23^{-}\end{array}$ & $\begin{array}{l}10 ; \text { to } \\
21^{\mathrm{c}}\end{array}$ & $\begin{array}{l}21 \text { to } \\
213^{-}\end{array}$ & 1 & $\begin{array}{c}0 ; 1 \text { to } \\
12^{-}\end{array}$ & $\begin{array}{l}12^{-} \text {to } \\
2^{-}\end{array}$ & 21 to 2 & $\begin{array}{c}10 ; 2 \text { to } \\
2^{-}\end{array}$ & 12 \\
\hline O'Connor & $?$ & $\begin{array}{c}0 ; \text { to } \\
0 ; 1\end{array}$ & 0 & 0 & 12 to 21 & 0 & $0 ; 1$ & 0 & $\begin{array}{c}1^{+} \text {to } \\
12^{-}\end{array}$ & 0 & $0 ;-1$ & 0 & 0 \\
\hline $\begin{array}{l}\text { Pacific } \\
\text { Ranger }\end{array}$ & $?$ & $\begin{array}{c}00 ; \text { to } \\
0 ; 1=\end{array}$ & $\begin{array}{l}0 ; \text { to } \\
0 ; 1^{-}\end{array}$ & $\begin{array}{l}0 ; 1 \text { to } \\
10 ; 2^{-}\end{array}$ & $\begin{array}{c}23^{-} \text {to } \\
3^{-}\end{array}$ & $\begin{array}{c}0 ; 1^{-} \text {to } \\
0 ; 1\end{array}$ & $\begin{array}{l}0 \text {; to } \\
120\end{array}$ & 00 & $\begin{array}{l}0 \text {; to } \\
120\end{array}$ & 00 & $; 1$ & $\begin{array}{c}00 \text {; to } \\
0 ; 1^{-}\end{array}$ & $\begin{array}{l}; 1 \text { to } \\
12^{-}\end{array}$ \\
\hline Vlamingh & $?$ & $\begin{array}{c}0 ; 1^{-} \text {to } \\
0 ; 1\end{array}$ & $\begin{array}{l}0 ; \text { to } \\
0 ; 1^{-}\end{array}$ & $213^{-}$ & $33^{+}$ & $\begin{array}{l}0 ; 1 \text { to } \\
10\end{array}$ & $\begin{array}{c}213^{-} \text {to } \\
23^{-}\end{array}$ & $0 ; 1$ & 1 to $12^{-}$ & $0 ; 1^{-}$ & $\begin{array}{c}0 ; 1^{-} \text {to } \\
; 1^{-}\end{array}$ & $0 ; 1^{-}$ & $\begin{array}{l}0 ; 1^{-} \text {to } \\
; 1\end{array}$ \\
\hline Yerong & $?$ & $0 ; 1$ & $\begin{array}{c}0 ; \text { to } \\
0 ; 1\end{array}$ & $\begin{array}{c}21 \text { to } \\
3-2\end{array}$ & $33^{-}$ & $\begin{array}{c}12^{-} 0 ; \text { to } \\
213^{-}\end{array}$ & $\begin{array}{l}21 \text { to } \\
213^{-}\end{array}$ & $0 ; 1$ & $10 ; 2^{-}$ & $\begin{array}{c}0 ; \text { to } \\
0 ; 1\end{array}$ & $; 1$ & $\begin{array}{c}0 ; 1^{=} \text {to } \\
12^{-}\end{array}$ & 0 \\
\hline
\end{tabular}

a Barley seedlings were scored using a modified 0-to-4 IT scale, based primarily on uredinial size $(20,21)$. The ITs recorded, therefore, indicate the most common pustule, followed by the next most common pustule, where IT $0=$ no visible symptoms, $;=$ hypersensitive flecks, $1=$ minute uredinia surrounded by mainly necrotic tissue, $2=$ small to medium-sized uredinia surrounded by chlorotic or necrotic tissue, $3=$ medium to large uredinia with or without surrounding chlorosis, and $4=$ large uredinia without chlorosis. The letter ' $c$ ' indicates greater than normal chlorosis; '-' or '+' indicate lower or higher ITs than normal, respectively. ITs of $3+$ or higher were considered to indicate compatibility (i.e., virulent pathogen/susceptible host). Where an IT range is observed, both the lowest and highest IT reaction are presented.

b Resistance allele.

Table 5. Frequency of stem rust resistant $(\mathrm{R})$ and susceptible (S) lines in the 'Yerong'/'Franklin' doubled haploid population

\begin{tabular}{|c|c|c|c|c|c|}
\hline \multirow[b]{2}{*}{ Pathotype or marker } & \multicolumn{2}{|c|}{ Observed frequency } & \multirow[b]{2}{*}{ Tested ratio } & \multirow[b]{2}{*}{$\chi^{2 \mathrm{a}}$} & \multirow[b]{2}{*}{$P$ value } \\
\hline & $\mathbf{R}$ & $\mathbf{S}$ & & & \\
\hline $98-1,2,3,5,6$ & 66 & 85 & $1: 1$ & 2.39 & 0.12 \\
\hline MCCJ & 119 & 32 & $3: 1$ & 1.17 & 0.28 \\
\hline RPG1-N marker & 105 & 46 & $1: 1$ & 23.05 & $<0.001$ \\
\hline
\end{tabular}

${ }^{\text {a }} \chi^{2}=3.84$ (1d.f.) at $P=0.05$. 
type reactions when tested with 98-1,2,3,5,6. Intermediate type reactions were observed on the susceptible check lines 'Steptoe' and ' 80 -tt-30' that were indistinguishable from lines shown to carry Rpg 1; therefore, it is not possible to differentiate genotypes with and without Rpgl using Australian pathotype 98-1,2,3,5,6. The inability to differentiate lines with Rpgl using $P$. graminis $\mathrm{f}$. sp. tritici pathotypes was reported previously in tests with pathotypes QFC and TPM (37,39). Sun and Steffenson (44) demonstrated that Rpgl could be detected reliably at the seedling stage using pathotypes MCCJ, HPH, and HKHJ. In this study, pathotypes MCCJ, HFCJ, and HKCJ clearly differentiated lines carrying Rpgl ('80-TT-29', 'Chevron', 'Empress', 'Pacific Ranger', 'Vlamingh', and 'Yerong') from those lacking Rpgl ('80-tt30 ' and 'Steptoe'). This was more noticeable at high incubation temperatures.

Seedling stem rust reactions in barley are influenced by incubation temperature and, generally, a higher infection type (or increased susceptibility) is observed at higher incubation regimes $(22,28,43)$. In this study, seedlings were maintained postinfection at low and high incubation temperatures. As indicated above, gene Rpg1 was most clearly differentiated at the high temperature regime, which is in agreement with previous findings by Steffenson (37). Thus, detection of gene Rpgl is best using incubation temperatures near $25^{\circ} \mathrm{C}$. In contrast, some resistance genes are functional at low temperatures only (43). This has been reported with rpg4 (14) and rpg6 (10). In this study, Australian barley stem rust differential 119Y4 produced a much higher infection type reaction $\left(2^{++}\right)$when incubated at the high temperature regime, compared with the clearly lower infection type $\left(;^{n}\right)$ when incubated at a low temperature. Doolup similarly appears to be governed by a temperature-sensitive gene, with very distinct infection type differences at low and high temperatures. Furthermore, 'Vlaming'h also appears to carry a gene or genes in addition to Rpgl that conditions resistance to pathotype SPMK at low incubation temperature.

Six Australian barley cultivars were tested against six North American stem rust pathotypes (MCCJ, QCCJ, SPMK, TTTT,

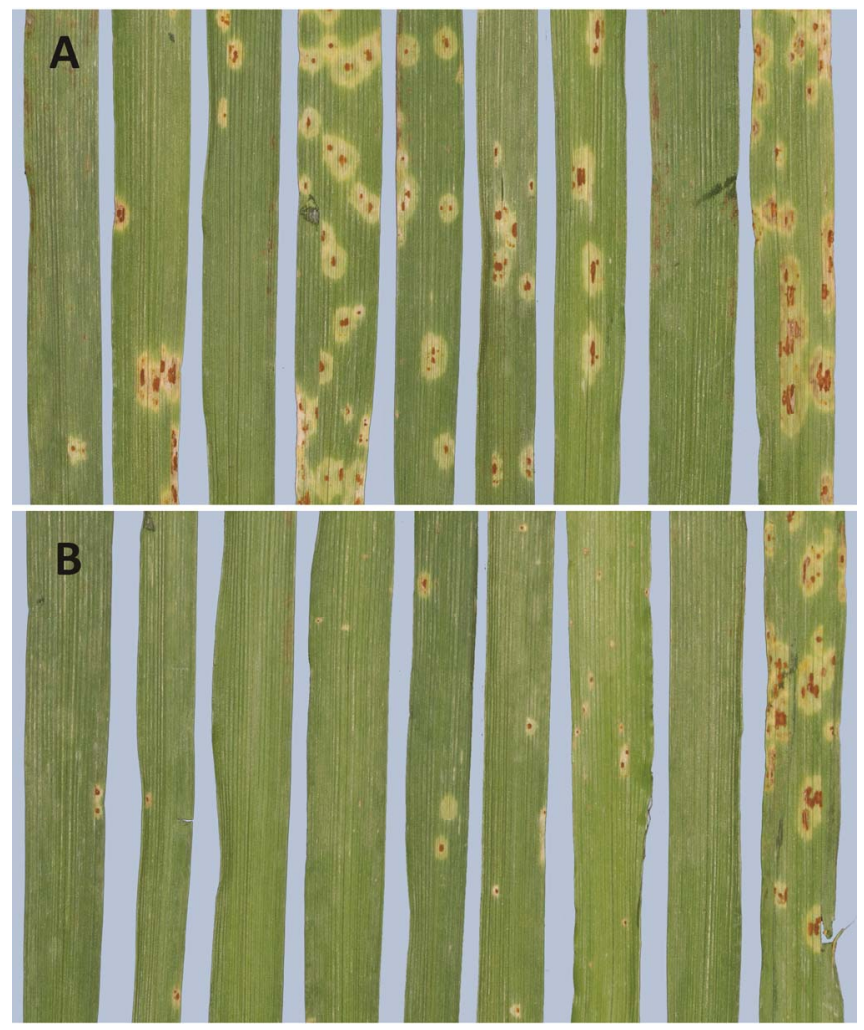

Fig. 2. Reaction of barley cultivars to Puccinia graminis $\mathrm{f}$. sp. tritici incubated at 23 to $27^{\circ} \mathrm{C}$ to A, QCCJ and B, MCCJ. From left to right: 'O'Connor', 'Empress', 'Pacific Ranger', 'Vlamingh', 'Franklin', 'Yerong', 'Chevron', 'Q21861', and 'Steptoe'.
HFCJ, and HKCJ) in order to validate the presence of genes Rpg1 and Rpg5. Rpg1 was confirmed in 'Empress', 'Vlamingh', 'Pacific Ranger', and 'Yerong', because all exhibited low infection types to MCCJ and high infection types to QCCJ and were positive for the RPG1-N marker. In addition to Rpgl, 'Pacific Ranger' and 'Chevron' may carry additional genes for resistance to $P$. graminis f. sp. tritici because both were also resistant to SPMK. The relationship between these genes is currently unknown; however, based on the difference in infection types to 98$1,2,3,5,6$, it is likely that 'Pacific Ranger' and 'Chevron' carry different genes.

Based on pedigree information, resistance observed in 'Pacific Ranger' is likely due to 'PC11'. PC11 was shown to possess a single dominant gene effective against QCCJ (37). Although rpg4 and rpg6 are both effective against QCCJ $(10,14)$, they are recessive in nature (37). Based on marker analyses, 'Pacific Ranger' does not likely possess rpg4 because it did not carry Rpg5, which was recently determined to be required for rpg4-mediated resistance (1). Because rpg6 was transferred into $H$. vulgare from $H$. bulbsoum, it is unlikely that 'Pacific Ranger' carries this gene. Thus, it appears that the additional gene in Pacific Ranger is derived from PC11 and is unlikely to be either rpg4 or rpg6. Thirty-three lines amplified positive for the Rpg5-LRK marker only, suggesting the presence of a functional Rpg5 gene; however, none exhibited infection type reactions comparable with the control Q21861 and, thus, these lines likely lack one of the four genes required for rpg4-mediated resistance to $P$. graminis f. sp. tritici (46) or they posses rare Rpg5 alleles that cannot be detected using the PP2C insertion-specific primers (1). These rare alleles contain an intact S/TPK domain but contain a single base pair insertion or single-nucleotide polymorphism that results in a predicted, truncated RPG5 protein or an E1287A amino acid substitution, respectively, which results in putative nonfunctional RPG5 proteins.

'Franklin' exhibited low to intermediate infection types against all pathotypes screened. This response type was not observed in the

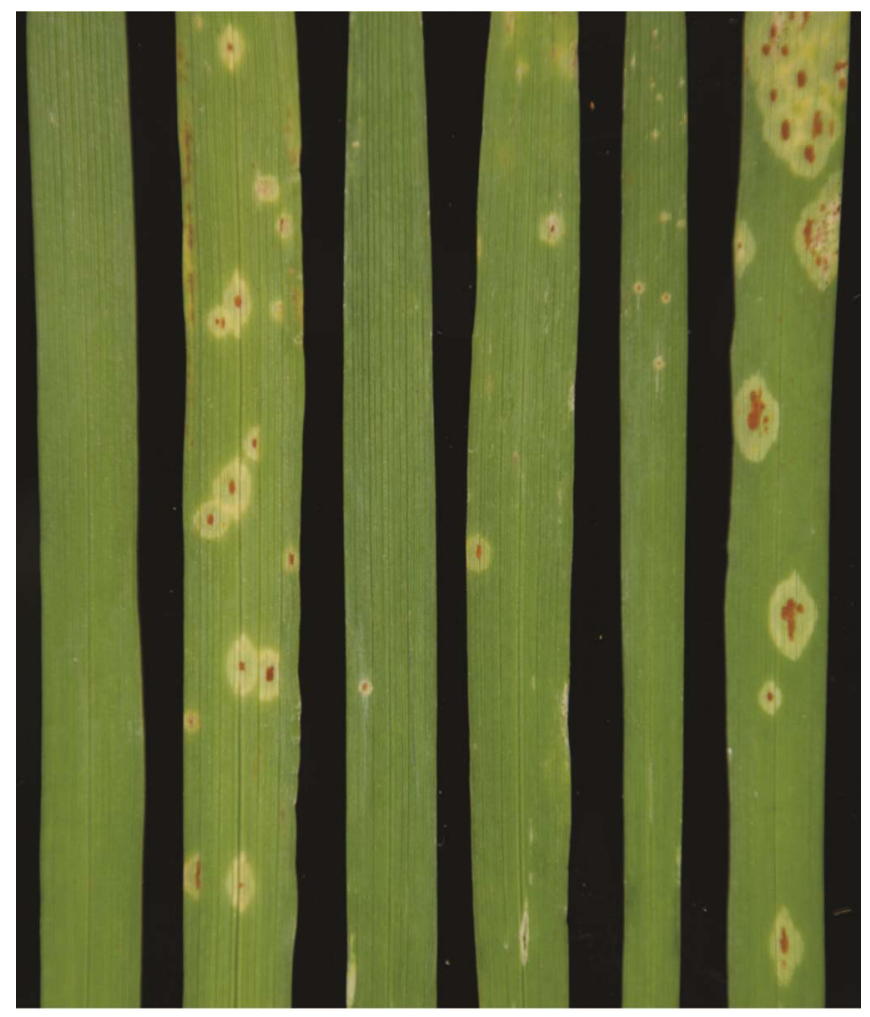

Fig. 3. Reaction of selected lines from a 'Yerong'/Franklin' DH population, along with parents and selected control genotypes when tested with Puccinia graminis f. sp. tritici pathotype MCCJ. From left to right: Q21861 (infection type = 0;), Steptoe (23-1), Yerong (0;), Franklin (120;), resistant progeny $\left(0 ; 1^{*}\right)$, and susceptible progeny $(3-23)$. Q21861 and Steptoe are resistant and susceptible controls, respectively. 
differential genotypes '80-TT-29' (Rpg1), 'Hietpas-5' (Rpg2), 'GAW-79' (Rpg3), 'Q2186'1 (Rpg1 + rpg4 + Rpg5), and '212Y1' (rpg6). When tested against pathotype MCCJ, segregation of the 'Yerong'/'Franklin' population fit a two-gene ratio. 'Yerong' was shown to carry Rpgl in multipathotype tests and marker analyses; therefore, the second gene is attributed to 'Franklin'. This suggests that resistance in Franklin is governed by a single gene independent of Rpgl. Lines more resistant than either parent were also observed. Jedel (13) showed that stem rust resistance genes Rpg1 and Rpg3 interact positively; therefore, it is possible that Rpgl and the resistance identified in 'Franklin' may also behave in an additive manner. When screened with pathotype 98$1,2,3,5,6$, 'Yerong' exhibited a $22^{+} 3$ infection type and was considered to lack effective seedling resistance, whereas 'Franklin' exhibited an intermediate infection type (21;), with the population segregating for a single gene. Joint segregant analysis of lines lacking Rpg1, based on the RPG1-N marker, indicate that the resistance genes in Franklin effective against MCCJ and 981,2,3,5,6 are different and appear independent of one another (data not presented).

Multipathotype tests using North American P. graminis f. sp. tritici pathotypes MCCJ and QCCJ revealed that 'Empress', 'Vlamingh', 'Pacific Ranger', and 'Yerong' carried Rpgl and support results obtained in marker analyses. However, although the RPG1$\mathrm{N}$ marker was effective at detecting the Rpgl gene in individual cultivars, distorted segregation ratios were observed when the marker was screened across the 'Yerong'/'Franklin' population. Eleven lines were positive for the RPG1-N marker but had disease ratings that were higher than $0 ; 1$. This suggests that there was an over representation of the Rpgl allele based on marker analysis. Of the 44 lines that lacked the Rpg1 marker, 23 were resistant to MCCJ; these lines likely carry resistance genes from both 'Yerong' and 'Franklin'. Of these, 11 were resistant to MCCJ but susceptible to 98-1,2,3,5,6 and represent lines that only carry Rpg1 (data not presented). Sayed et al. (33), using a total of 147 simple-sequence repeat (SSR) markers, studied the segregation ratios of a $\mathrm{DH}$ and an $F_{2}$ population in barley. They found that the $F_{2}$ population tended to have lower frequencies of distorted markers with higher variability between individual crosses, whereas distorted segregation ratios were found for SSR markers in the DH population, particularly on chromosomes $1 \mathrm{H}, 2 \mathrm{H}, 4 \mathrm{H}$, and $7 \mathrm{H}$. Rpgl was mapped to the short arm of chromosome $7 \mathrm{H}$ (3), where segregation distortion is believed to be quite common (19). The distortion on chromosome $7 \mathrm{H}$ is believed to be due to genetic effects (33). The occurrence of segregation distortion suggests that it is highly advisable to phenotype the population for resistance in the greenhouse or field. Phenotyping will also ensure that the detected gene is functional.

Although virulence to Rpgl has been reported, such as $P$. graminis f. sp. tritici pathotype 59A and QCCJ $(23,31)$, these pathotypes have not increased and become established and, presently, are at innocuous levels in the wheat stem rust population (37). A new threat to barley is $P$. graminis f. sp. tritici pathotype TTKS. This pathotype, more commonly referred to as Ug99, was first detected in Uganda in 1999 and has since spread through eastern Africa (Kenya, Ethiopia, and Sudan), crossing the Red Sea to Yemen (2006); and, more recently, its presence was confirmed in Iran (2007) $(24,35,47)$. TTKS has a wide virulence spectrum and is capable of attacking more than $70 \%$ of the world's wheat cultivars. It is also virulent on many barley cultivars, including those carrying Rpg1 $(36,38)$. Due to its rapid spread from Uganda and its ability to attack or cause severe yield damage on both wheat and barley, TTKS is considered a threat to global food security (36). Studies on the inheritance of resistance in cultivars that possess genes for stem rust resistance that are different from Rpg1 could provide useful information in breeding programs. In this study, resistance observed in 'O'Connor', 'Franklin', 'Quasar', and 'Quickstar' may be particularly useful, because these cultivars were also shown to be seedling resistant to Ug99 (R. F. Park, unpublished). However, the level of resistance imparted by these genes under field conditions is unknown and further tests are needed to determine their value.

In Australia, yield losses to stem rust in susceptible barley cultivars can be as high as $49 \%$, with epidemics developing rapidly in some barley cultivars (7). In this study, a number of potentially useful stem rust resistance genes have been identified. Genetic studies are needed to characterize these resistance sources. In order to assess their value to agriculture, it is important to determine the level of protection conferred by these resistances under field conditions because a low correlation has been found between seedling and adult plant reactions in barley to stem rust $(7,16)$.

\section{Acknowledgments}

This research was supported by the Australian Grains and Research Development Corporation through a Postgraduate Research Scholarship (GRS139). Travel to the CRC was supported by the Farrer Memorial Travelling Scholarship. We thank H. Karaoglu for valuable suggestions and advice and P. Kavanagh and $\mathrm{M}$. Williams for valuable technical support

\section{Literature Cited}

1. Arora, D., Gross, T., and Brueggeman, R. 2013. Allele characterization of genes required for rpg4-mediated wheat stem rust resistance identifies Rpg5 as the $R$ gene. Phytopathology 103:1153-1161.

2. Brueggeman, R., Druka, A., Nirmala, J., Cavileer, T., Drader, T., Rostoks, N., Mirlohi, A., Bennypaul, H., Gill, U., Kudrna, D., Whitelaw, C., Kilian, A. Han, F., Sun, Y., Gill, K., Steffenson, B., and Kleinhofs, A. 2008. The stem rust resistance gene Rpg5 encodes a protein with nucleotide-bindingsite, leucine-rich and protein kinase domains. Proc. Natl. Acad. Sci. USA 105:14970-14975.

3. Brueggeman, R., Rostoks, N., Kudrna, D., Kilian, A., Han, F., Chen, J., Druka, A., Steffenson, B., and Kleinhofs, A. 2002. The barley stem rustresistance gene Rpgl is a novel disease-resistance gene with homology to receptor kinases. Proc. Natl. Acad. Sci. USA 99:9328-9333.

4. Brueggeman, R., Steffenson, B. J., and Kleinhofs, A. 2009. The rpg4/Rpg5 stem rust resistance locus in barley. Cell Cycle 8:1-5.

5. Dellaporta, S.L., Wood, J., and Hicks, S. L. 1983. A plant DNA minipreparation: Version II. Plant Mol. Biol. Rep. 1:19-21.

6. Derevnina, L., Fetch, T., Jr., and Park, R. 2011. Resistance to stem rust in Australian barley cultivars In: Borlaug Global Rust Initiative Technical Workshop. R. A. McIntosh, ed. St. Paul, MN.

7. Dill-Macky, R. 1992. The epidemiology and management of stem rust in barley in North-Eastern Australia. Ph.D. dissertation, The University of Queensland, Australia.

8. Dill-Macky, R., Ress, R. G., and Platz, G. J. 1990. Stem rust epidemics and their effects on grain yield and quality in Australian barley cultivars. Aust. J. Agric. Res. 41:1057-1063.

9. Eckstein, P., Rossnagel, B., and Scoles, G. 2003. Allele-specific markers within the barley stem rust resistance gene (Rpg1). Barley Genet. Newsl. 33:7-11.

10. Fetch, T., Johnston, P. A., and Pickering, R. 2009. Chromosomal location and inheritance of stem rust resistance transferred from Hordeum bulbosum into cultivated barley (H. vulgare). Phytopathology 99:339-343.

11. Fox, S. L., and Harder, D. E. 1995. Resistance to stem rust in barley and inheritance of resistance to race QCC. Can. J. Plant Sci. 75:781-788.

12. Jedel, P. E., 1990. A gene for resistance to Puccinia graminis f. sp. tritici in PI 382313. Barley Genet. Newsl. 20:43-44.

13. Jedel, P. E., Metcalfe, D. R., and Martens, J. W. 1989. Assessment of barley accessions PI 382313, PI 382474, and PI 382976 for stem rust resistance. Crop Sci. 29:1473-1477.

14. Jin, Y., Steffenson, B. J., and Miller, J. D. 1994. Inheritance of resistance to pathotypes QCC and MCC of Puccinia graminis f. sp. tritici in barley line Q21861 and temperature effects on the expression of resistance. Phytopathology 84:452-455.

15. Johnson, R. 1984. A critical analysis of durable resistance. Annu. Rev. Phytopathol. 22:309-330.

16. Johnson, T., and Buchannon, K. W. 1954. The reaction of barley varieties to rye stem rust, Puccinia graminis var. secalis. Can. J. Agric. Res. 34:473482.

17. Kilian, A., Chen, J., Han, F., Steffenson, B., and Kleinhofs, A. 1997. Towards map-based cloning of the barley stem rust resistance genes Rpg1 and rpg4 using rice as an intergenomic cloning vehicle. Plant Mol. Biol. 35:187195.

18. Luig, N. H., and Watson, I. A. 1972. The role of wild and cultivated grasses in the hybridization of formae speciales of Puccinia graminis. Aust. J. Biol. Sci. 25:335-342.

19. Manninen, O. M. 2000. Association between anther-culture response and molecular markers on chromosomes $2 \mathrm{H}, 3 \mathrm{H}$ and $4 \mathrm{H}$ of barley (Hordeum vulgare L.). Theor. Appl. Genet. 100:57-62.

20. McIntosh, R. A. 1992. Pre-emptive breeding to control wheat rusts. Euphytica $63: 103-113$

21. McIntosh, R. A., Wellings, C. R., and Park, R. F. 1995. Wheat Rusts: An 
Atlas of Resistance Genes. Kluwer Academic Publishers, London.

22. Miller, J. D., and Lambert, J. W. 1955. Variability and inheritance of reaction of barley to race 15B of stem rust. Agron. J. 47:373-377.

23. Miller, J. D., and Lambert, J. W. 1956. Reactions of certain spring barley lines to race 59A of stem rust. Plant Dis. Rep. 40:340-346.

24. Nazari, K., Mafi, M., Yahyaoui, A., Singh, R. P., and Park, R. F. 2009. Detection of wheat stem rust (Puccinia graminis $\mathrm{f}$. sp. tritici) race TTKSK (Ug99) in Iran. Theor. Appl. Genet. 93:317.

25. Park, R. F. 2007. Stem rust of wheat in Australia. Aust. J. Agric. Res. 58:558-566.

26. Park, R. F. 2008. Breeding cereals for rust resistance in Australia. Plant Pathol. 57:591-602.

27. Park, R. F., and Karakousis, A. 2002. Characterization and mapping of gene Rph19 conferring resistance to Puccinia hordei in the cultivar 'Reka 1' and several Australian barleys. Plant Breed. 121:232-236.

28. Patterson, F. L., Shands, R. G., and Dickson, J. G. 1957. Temperature and seasonal effects on seedling reactions of barley varieties to three races of Puccinia graminis f. sp. tritici. Phytopathology 47:395-402.

29. Powers, L., and Hines, L. 1933. Inheritance of reaction to stem rust and barbing awns in barley crosses. J. Agric. Res. 46:1121-1129.

30. Roelfs, A. P. 1985. Wheat and rye stem rust. Page 3-37 in: The Cereal Rusts, Vol. 2. A. P. Roelfs and W. R. Bushnell, eds. Academic Press, Sydney, Australia.

31. Roelfs, A. P., Casper, D. H., Long, D. L., and Roberts, J. J. 1991. Races of Puccinia graminis in the United States in 1989. Plant Dis. 75:1127-1130.

32. Roelfs, A. P., and Martens, J. W. 1988. An international system of nomenclature for Puccinia graminis f. sp. tritici. Phytopathology 78:226-533.

33. Sayed, H., Kayyal, H., Ramsey, L., Caeccarelli, S., and Baum, M. 2002. Segregation distortion in double haploid lines of barley (Hordeum vulgare L.) detected by simple sequence repeat (SSR) markers. Euphytica 225:265272 .

34. Shands, R. G. 1939. Chevron, a barley variety resistant to stem rust and other diseases. Phytopathology 29:209-211.

35. Singh, R. P., Hodson, D. P., Huerta-Espino, J., Jin, Y., Njau, P., Wanyera, R., Herrera-Foessel, S. A., and Ward, R. W. 2008. Will stem rust destroy the world's wheat crop? Adv. Agron. 98:271-309.

36. Steffenson, B., and Jin, Y. 2006. Resistance to race TTKS of Puccinia graminis f. sp. tritici in barley (Abstr.). Phytopathology 96:S110.

37. Steffenson, B. J. 1992. Analysis of durable resistance to stem rust in barley.
Euphytica 63:153-167.

38. Steffenson, B. J., Jin, Y., Brueggeman, R. S., Kleinhofs, A., and Sun, Y. 2009. Resistance to stem rust race TTKSK maps to the rpg4/Rpg5 complex of chromosome $5 \mathrm{H}$ of barley. Phytopathology 99:1135-1141.

39. Steffenson, B. J., Miller, J. D., and Jin, Y. 1993. Detection of the stem rust resistance gene Rpg1 in barley seedlings. Plant Dis. 77:626-629.

40. Steffenson, B. J., Olivera, P., Roy, J. K., Jin, Y., Smith, K. P., and Muehlbauer, G. J. 2007. A walk on the wild side: Mining wild wheat and barley collections for rust resistance genes. Aust. J. Agric. Res. 58:532-544.

41. Steffenson, B. J., and Wilcoxson, R. D. 1987. Receptivity of barley to Puccinia graminis f. sp. tritici. Can. J. Plant Pathol. 9:36-40.

42. Steffenson, B. J., Wilcoxson, R. D., and Roelfs, A. P. 1984. Inheritance of resistance to Puccinia graminis f. sp. secalis in barley. Plant Dis. 68:762763.

43. Steffenson, B. J., Wilcoxson, R. D., and Roelfs, A. P. 1985. Resistance of barley to Puccinia graminis f. sp. tritici and Puccinia graminis f. sp. secalis. Phytopathology 75:1108-1111.

44. Sun, Y., and Steffenson, B. J. 2005. Reaction of barley seedlings with different stem rust resistance genes to Puccinia graminis f. sp. tritici and Puc cinia graminis f. sp. secalis. Can. J. Plant Pathol. 27:80-89.

45. Sun, Y., Steffenson, B. J., and Jin, Y. 1996. Genetics of resistance to Puccinia graminis f. sp. secalis in barley line Q21861. Phytopathology 86:1299-1302.

46. Wang, X., Richards, J., Gross, T., Druka, A., Kleinhofs, A., Steffenson, B., Acevedo, M., and Brueggeman, R. 2013. The rpg4-mediated resistance to wheat stem rust (Puccinia graminis) in barley (Hordeum vulgare) requires Rpg5, a serine NBS-LRR gene, and an actin depolymerization factor. Mol. Plant-Microbe Interact. 26:407-418.

47. Wanyera, R., Kinyua, M. G., Jin, Y., and Singh, R. P. 2006. The spread of stem rust caused by Puccinia graminis f. sp. tritici, with virulence on $\mathrm{Sr} 31$ in wheat in Eastern Africa. Plant Dis. 90:113

48. Waterhouse, W. L. 1929. Australian rust studies I. Proc. Linn. Soc. N. S. W. 54:615-680.

49. Watson, I. A., and Luig, N. H. 1963: The classification of Puccinia graminis var. tritici in relation to breeding resistant varieties. Proc. Linn. Soc. N. S. W. $88: 235-258$

50. Zhang, L., Castell-Miller, C., Dahl, S., Steffenson, B., and Kleinhofs, A 2008. Parallel expression profiling of barley-stem rust interactions. Functional and Integrative Genomics 8:187-198. 